\title{
Penerapan Metode Boosting Pada Cart Untuk Mengklasifikasikan Korban Kecelakaan Lalu Lintas Di Kota Palu
}

\section{(Application Of Boosting Methods On Cart For Classification Of Traffic Accidents In Palu City)}

\author{
Luluk Susiana ${ }^{1^{\star}}$, Iut Tri Utami ${ }^{{ }^{*}}$ dan Junaidi ${ }^{1}$ \\ 1 Jurusan Matematika Fakultas MIPA, Universitas Tadulako Jl. Soekarno Hatta Km 9 Tondo Palu 94118 Sulawesi \\ Tengah.
}

Keywords: Boosting Method, Accuracy of Classification, and Traffic Accidents.

Keywords: Metode Boosting, Ketepatan Klasifikasi, Kecelakaan Lalu Lintas.

${ }^{*}$ Coresponding Author: luluksusiana01@gmail.com, Triutami.iut@gmail.com

\begin{abstract}
Palu City, the capital city of Central Sulawesi Province, has a high traffic accident which is there are around 365 deaths every year. Traffic accidents are influenced by several factors, violations, and accidents, etc. The objectives to be achieved in this study are to determine the accuracy of the classification of victims of traffic accidents in the city of Palu using the boosting method and the factors that influence it. The results of this study indicate that the accuracy of the boosting method classification is $82 \%$ and the CART method is $77.9 \%$. These results indicate that the boosting method can increase the level of accuracy. While the factors that influence the victims of traffic accidents in Palu City are factors in the type of accident (X1), the role of victims in accidents (X4), types of violations (X7) and age (X3) victims of traffic accidents in Palu City.
\end{abstract}

\begin{abstract}
Abstrak
Kota Palu sebagai ibu kota Provinsi Sulawesi Tengah dengan kecelakaan lalu lintas yang cukup tinggi yang setiap tahunnya memiliki kematian sekitar 365 jiwa. Kecelakaan lalu lintas dipengaruhi oleh beberapa faktor, diantaranya jenis pelanggaran, jenis kecelakaan, dan lain-lain. Tujuan yang akan dicapai dalam penelitian ini adalah untuk menentukan ketepatan klasifikasi pada korban kecelakaan lalu lintas di Kota Palu dengan menggunakan metode boosting serta faktor-faktor yang mempengaruhinya. Hasil dari penelitian ini menunjukkan bahwa ketepatan klasifikasi metode boosting sebesar $82 \%$ dan metode CART sebesar $77,9 \%$. Hasil tersebut menunjukkan bahwa metode boosting dapat meningkatan tingkat akurasi. Sedangkan faktor-faktor yang mempengaruhi korban kecelakaan lalu lintas di Kota Palu adalah faktor jenis kecelakaan (X1), peran korban dalam kecelakaan (X4), jenis pelanggaran (X7) dan usia (X3) korban kecelakaan lalu lintas di Kota Palu.
\end{abstract}

\section{Latar Belakang}

Sebagai salah satu kota di Indonesia, Kota Palu memiliki tingkat kecelakaan lalu lintas yang cukup tinggi. Catatan Badan Pusat Statistik (BPS) menyatakan bahwa tahun 2009 total kecelakaan di Kota Palu sebanyak 1.222 dan pada tahun 2010 sebanyak 1.359, sehingga memerlukan perhatian serius dari semua pihak termasuk para pengguna transportasi di daerah ini. Tingginya tingkat kecelakaan di Kota Palu dengan berbagai faktor menjadi dasar pentingnya dalam penelitian ini. 
Korban kecelakaan lalu lintas di Kota Palu dapat diklasifikasikan dengan menggunakan data yang menghasilkan ketepatan klasifikasi yang baik. Nilai ketepatan klasifikasi pada data mining dapat dihasilkan dari klasifikasi tunggal dan klasifikasi gabungan. Klasifikasi tunggal diantaranya adalah metode CART, SVM, KNN, regresi logistik, dan lain-lain. Sedangkan pada klasifikasi gabungan (ensamble) diantaranya adalah boosting, bagging, dan random forest. Metode ensamble merupakan metode dengan ide melakukan kombinasi dari banyak classifier tunggal dimana hasil prediksi masing-masing classifier digabungkan menjadi prediksi akhir melalui proses voting dengan suara terbanyak (Jamal, Bambang, dan Santi, 2012).

Boosting adalah salah satu metode ensamble yang digunakan untuk meningkatkan akurasi dari model klasifikasi dengan cara membangkitkan kombinasi dari suatu model (Hidayanti, 2015). Berbeda halnya dengan bagging dan random forest yang mendapatkan hasil prediksi dari proses bootstrap, boosting mengacu pada kumpulan algoritma yang dapat mengkombinasikan pengklasifikasian lemah menjadi pengklasifikasian yang kuat sehingga mendapatkan tingkat keakurasian yang tinggi dalam klasifikasinya. Boosting juga di kenal dengan sebutan Adaboost (Adaptive Boosting).

Penelitian yang terkait kecelakaan lalu lintas pernah dilakukan oleh Fitriah, Mashuri, dan Irhamah (2012) mengenai faktor-faktor yang mempengaruhi korban kecelakaan lalu lintas di Kota Surabaya menggunakan pendekatan bagging regresi logistik ordinal dengan hasil analisis menunjukkan bahwa ketepatan klasifikasi menggunakan bagging regresi logistik ordinal lebih baik yaitu sebesar $56 \%$ dibandingkan dengan hasil ketepatan klasifikasi regresi logistik ordinal yaitu sebesar $54,86 \%$. Penelitian tentang metode boosting juga dilakukan oleh Jamal, Bambang, dan Santi (2012) mengenai metode ensamble (bagging dan boosting) untuk perbaikan klasifikasi kemiskinan di Kabupaten Jombang dengan hasil analisis menunjukan bahwa akurasi bagging klasifikasi kelas sangat miskin sebesar $20,26 \%$ dibandingkan dengan boosting sebesar $75,96 \%$.

Dalam penelitian ini, digunakan delapan variabel jenis data kecelakaan lalu lintas yaitu satu variabel respon dan tujuh variabel prediktor. Tujuan dalam penelitian ini adalah untuk menentukan ketepatan klasifikasi pada data korban kecelakaan lalu lintas di Kota Palu dengan menggunakan metode boosting dan untuk mengetahui faktor-faktor yang mempengaruhuinya. Manfaat dalam penelitian ini adalah dapat memberikan informasi kepada unit Laka Satlantas Polres Kota Palu terkait faktor-faktor apa saja yang mempengaruhi korban kecelakaan lalu lintas di Kota Palu tahun 2018, sehingga diharapkan Satlantas Polres Palu memberikan perhatian yang lebih terhadap faktorfaktor tersebut dan dapat menjadi refisi untuk antisipasi jatuhnya korban kecelakaan lalu lintas di Palu.

\section{Bahan dan Metode}

Lokasi penelitian dilakukan di kantor Polres Kota Palu, Sulawesi Tengah. Data yang digunakan dalam penelitian ini adalah data yang diperoleh dari data Korban Kecelakaan Lalu Lintas Di Kota Palu tahun 2018 yang diperoleh dari laporan unit Laka Satlantas Polres Palu. Jenis data dan variabel yang digunakan adalah sebagai berikut:

a. Variabel Respon (Y)

Pada penelitian ini variabel respon yang digunakan adalah tingkat keparahan korban kecelakaan lalu lintas dengan kategori sebagai berikut;

- Korban meninggal $(\mathrm{KM})=0$

- Korban luka berat $(\mathrm{KLB})=1$

- Korban luka ringan $(K L R)=2$

b. Variabel Prediktor $(X)$

1. Jenis Kecelakaan $\left(X_{1}\right)$

- Tabrakan depan (TD) =0

- Tabrakan belakang (TB) $=1$

- Tabrakan samping (TS) $=2$

- Lain-lain = 3

2. Jenis Kelamin $\left(X_{2}\right)$

- Laki-laki=0

- Perempuan $=1$

3. Usia $\left(\mathrm{X}_{3}\right)$

- Anak-anak dan remaja $(0-17$ tahun $)=0$

- Dewasa (18-50 tahun) $=1$

- Lanjut usia (>50 tahun) $=2$

4. Peran Korban Dalam kecelakaan $\left(\mathrm{X}_{4}\right)$

- Pengendara $=0$

- Penumpang kendaraan selain pengendara $=1$

- Pengguna jalan (penyeberang jalan, pejalan kaki dII) $=2$

5. Jenis Kendaraan $\left(X_{5}\right)$

- Sepeda motor (dua atau tiga roda) $=0$

- Mobil (empat roda) $=1$

6. Waktu Kecelakaan $\left(\mathrm{X}_{6}\right)$

- Padat kendaraan (pukul 06.00 - 08.30 WITA, pukul $11.30-14.00$ WITA, pukul $16.00-18.30$ WITA) $=0$

- Sepi (selain waktu padat $)=1$

7. Jenis pelanggaran $\left(X_{7}\right)$ 
- Kecepatan tinggi (tidak hati-hati) $=0$

- Tidak jaga jarak = 1

- Kurang konsentrasi $=2$

Lain-lain $=3$.

\section{Hasil dan Pembahasan}

Data kecelakaan lalu lintas di Kota Palu yang sudah ada berjumlah 1000 data, yang akan dianalisis dengan bantuan software $\mathrm{R}$ dengan packages adabag dan caret. Data dibagi menjadi 2 bagian yaitu data training $75 \%$ sebanyak 750 data dan data testing $25 \%$ sebanyak 250 data. Data training yaitu data yang digunakan untuk membuat model boosting. Ukuran ini memperhitungkan kenaikan indeks Gini yang diberikan oleh variabel dalam tree dan bobot dari tree pada iterasi ke 100 sebab pada iterasi ke 100 hasil ketepatan klasifikasinya sudah konvergen. Prediksi dilakukan pada data testing yang digunakan untuk menentukan hasil ketepatan klasifikasi pada korban kecelakaan lalu lintas di Kota Palu yang dapat dilakukan dengan menghitung total accuracy rate, sensitivity, dan specificity.

\section{Metode CART}

Pada Tabel 1. dapat dilihat bahwa Observed Class dan predicted Class pada CART yang berhasil di prediksi tepat pada kelas Korban Luka Berat (KLB) sebanyak 10, pada kelas Korban Luka Ringan (KLR) sebanyak 747, dan pada kelas Korban Meninggal (KM) sebanyak 22. Total accuracy rate yang dihasilkan sebesar $77,9 \%$ yang artinya hasil ketepatan klasifikasi pada CART sebesar $77,9 \%$.

Tabel 1. Observed Class

\begin{tabular}{llll}
\hline \multirow{2}{*}{ Predicted Class } & \multicolumn{3}{l}{ Observed Class } \\
\cline { 2 - 4 } & KLB & KLR & KM \\
\hline KLB & 10 & 0 & 0 \\
KLR & 160 & 747 & 47 \\
KM & 8 & 6 & 22 \\
\hline Accuracy Rate & $77,9 \%$ & & \\
\hline Error Rate & $22,1 \%$ & & \\
\hline
\end{tabular}

Pada Tabel 2 menunjukkan bahwa variabel korban kecelakaan lalu lintas di kategorikan dengan tiga kategori yaitu korban luka berat, korban luka ringan, dan korban meninggal. Hasil sensitivity yang paling tinggi ada pada kategori korban luka ringan sebesar $99,20 \%$ dan specificity sebesar $16,19 \%$.

\section{Metode Boosting}

Pada Tabel 3. dapat dilihat bahwa Observed Class dan predicted Class pada metode boosting yang berhasil tepat di prediksi pada kelas Korban Luka Berat (KLB) sebanyak 6, pada kelas Korban Luka Ringan (KLR) sebanyak 194, dan pada kelas Korban Meninggal (KM) sebanyak 5. Total accuracy rate yang dihasilkan pada metode boosting sebesar $82 \%$ yang artinya hasil ketepatan klasifikasi pada metode boosting adalah $82 \%$.

Tabel 2. Sensitivity dan Specificity

\begin{tabular}{lccc}
\hline & KLB & KLR & KM \\
\hline Sensitivity & $5,618 \%$ & $99,20 \%$ & $31,88 \%$ \\
Specificity & $100 \%$ & $16,19 \%$ & $98,50 \%$ \\
\hline
\end{tabular}

Tabel 3. Observed Class

\begin{tabular}{|c|c|c|c|}
\hline \multirow{2}{*}{ Predicted Class } & \multicolumn{3}{|c|}{ Observed Class } \\
\hline & KLB & KLR & KM \\
\hline KLB & 6 & 0 & 2 \\
\hline KLR & 29 & 194 & 12 \\
\hline $\mathrm{KM}$ & 1 & 1 & 5 \\
\hline Accuracy Rate & & $82 \%$ & \\
\hline Error Rate & & $18 \%$ & \\
\hline
\end{tabular}

Pada Tabel 4. diketahui bahwa hasil nilai sensitivity pada metode boosting diprediksi sangat tinggi pada kelas korban luka ringan sebesar $99,49 \%$ dan Specificity sebesar $25,45 \%$. Dari hasil tersebut dapat disimpulkan bahwa korban kecelakaan lalu lintas pada kategorik korban luka ringan dapat diklasifikasikan korban kecelakaan benar-benar sebagai korban luka ringan sebesar $99,49 \%$.

Tabel 4. Sensitivity dan Specificity

\begin{tabular}{llll}
\hline & KLB & KLR & KM \\
\hline Sensitivity & $16,67 \%$ & $99,49 \%$ & $26,32 \%$ \\
Specificity & $99,07 \%$ & $25,45 \%$ & $99,13 \%$ \\
\hline
\end{tabular}

Perbandingan Metode Decision Tree dan Boosting

Pada Tabel 5. menunjukkan bahwa hasil accuracy rate pada metode boosting lebih baik atau lebih akurat sebesar $82 \%$ dibandingkan dengan hasil accuracy rate pada metode CART sebesar $77,9 \%$. Hal ini berarti metode boosting terbukti dapat meningkatkan hasil accuracy rate dibandingkan dengan CART. Semakin tinggi hasil accuracy rate yang di dapat maka data dapat diklasifikasikan dengan akurat. 
Pada Tabel 6. menunjukkan bahwa hasil sensitivity pada CART sebesar $99,20 \%$ pada kelas korban luka ringan dan specificity sebesar $16,19 \%$. Hasil sensitivity pada boosting sebesar $99,49 \%$ pada kelas korban luka ringan dan specificity sebesar $25,45 \%$. Artinya metode boosting pada hasil sensitivity dan specificity lebih baik dibandingkan dengan metode CART.

Tabel 5. Perbandingan Accuracy

\begin{tabular}{lc}
\hline \multicolumn{1}{c}{ Metode } & Accuracy Rate \\
\hline CART & $77,9 \%$ \\
Boosting & $82 \%$ \\
\hline
\end{tabular}

Menentukan faktor-faktor yang mempengaruhi korban kecelakaan lalu lintas di Kota Palu.

Untuk menentukan faktor-faktor yang mempengaruhi korban kecelakaan lalu lintas di Kota Palu dapat di lihat pada lampiran 3. Bagian pembentukan model boosting kemudian didalam model boosting terdapat pohon atau tree pada iterasi 100 yang menunjukkan bahwa kecelakaan lalu lintas yang sangat mempengaruhi korban kecelakaan lalu lintas di Kota Palu yaitu pada variabel jenis kecelakaan $\left(X_{1}\right)$, peran korban dalam kecelakaan $\left(X_{4}\right)$, jenis pelanggaran $\left(X_{7}\right)$ dan usia $\left(X_{3}\right)$.

Tabel 6. Perbandingan Sensitivity dan Specificity

\begin{tabular}{lllllll}
\hline \multirow{2}{*}{ Metode } & \multicolumn{2}{c}{ Sensitivity (\%) } & \multicolumn{4}{c}{ Specificity (\%) } \\
\cline { 2 - 7 } & KLB & KLR & KM & KLB & KLR & KM \\
\hline CART & 5,61 & 99,20 & 31,88 & 100 & 16,19 & 98,50 \\
Boosting & 16,67 & 99,49 & 26,32 & 99,07 & 25,45 & 99,13
\end{tabular}

Berdasarkan hasil dan pembahasan yang telah dilakukan sebelumnya, maka dapat diperoleh beberapa kesimpulan sebagai berikut:

a. Hasil ketepatan klasifikasi pada korban kecelakaan lalu lintas di Kota Palu dengan menggunakan metode boosting lebih baik yang hasilnya sebesar $82 \%$ dibandingkan dengan metode CART yang hasilnya sebesar $77,9 \%$. Hasil nilai sensitivity atau kemampuan metode boosting yang paling tepat diprediksi pada kelas korban luka Ringan sebesar 99,49\% dan specificity sebesar $25,45 \%$. Jadi, hasil sensitivity yang tinggi maka hasil specificity akan rendah begitu juga sebaliknya.

b. Faktor-faktor yang berpengaruh terhadap korban kecelakaan lalu lintas di Kota Palu dengan menggunakan metode Boosting adalah jenis kecelakaan $\left(X_{1}\right)$, peran korban dalam kecelakaan $\left(X_{4}\right)$, jenis pelanggaran $\left(X_{7}\right)$ dan usia $\left(X_{3}\right)$.

\section{Daftar Pustaka}

Dua, S. \& Xian Du., 2011, Data Mining and Machine Learning in Cybersecurity. USA: Taylor \& Francis Group. ISBN-13: 978-1-4398-3943-0

Freund, Y., 1995, Boosting Weak Learning Algorithm by majority. Information and Computation, 121, 256-285.

Freund, Y., and Schapire, R. E., 1996, Experiments With A New Boosting Algorithm. Machine Learning: Proceedings Of The Thirteenth International Conference, Morgan Kauffman, San Francisco: 148-156.

Gorunescu, F., 2011, Data Mining Concept Model and Techniques. Berlin: Springer.

Hidayanti, A. A., 2015, Boosting Multivariate Adaptive Regression Spline (MARS) Binary Response Untuk Klasifikasi Kemiskinan Di Kabupaten Jombang, Jurnal Valid, 12 (4): 388 - 398.

https://www.searo.who.int/kecelakaan lalu lintas/di akses pada tanggal 12 mei 2018.

https://www.ditlantas-polda sulteng.net/ Tingkat Keparahan kecelakaan lalu Intas di kota palu (diakses pada tanggal 22 februari 2013).

Jamal, M. M., Bambang. W., dan Santi, R., 2012, Metode Ensamble (Bagging dan Boosting) Untuk Perbaikan Klasifikasi Kemiskinan Dikabupaten Jombang. JNTETI, 5: No 4.

Larose, D. T., 2005, Discovering Knowledge in Data. New Jersey: John Willey \& Sons, Inc. ISBN 0471-66657-2. 